\title{
農村女性のキャリア形成に関する研究 一農村女性のキャリア形成を構成する要素について检討一
}

\author{
仁平 章子（賢明女子学院短期大学） \\ 加古 敏之（神戸大学農学部）
}

\section{1. 課題と目的}

近年，農業就業人口の高齢化が加速するとともに農 業就業人口の数む年々減少傾向で推移している. 農業 就業者の男女比率を見ると，女性の占める割合は昭和 45 年から平成 7 年までは約 6 割で推移しているが, 平成 12 年からは $55 \%$ 台となり, 男女の構成比率の差 は減少しつつあるあのの依然として女性が高い比率を 占めている. また, 農家の主業副業別に農業就業人口 の男女別構成割合をみると, 準主業農家では女性の構 成比は $62.1 \%$, 副業的農家では $54.4 \%$ である。この ように女性が占める農業就業人口が高い背景のもとで 農業に携わる女性が, 農業経営, 農村生活で重要な役 割を担うことが期待されている。農家女性が重要な役 割を果たすためにはキャリアを形成することが重要で ある。

本稿では最初に農村女性のキャリア形成の分析枠組 を構築し，ついでその理論的フレーム枠を用いて農家 女性の 3 事例を分析する。

\section{2.キャリア形成の概念}

キャリアとは，狭義には，一人の人間がその人生を たどっていく職業経歴であり, 時系列的な職業のつな がりである. 広義には, 一人の人間の生涯の生活プラ ンを含めたあのと捉えることもできる，農村社会にお いて, 農村女性が農業に従事することは, ただ生活の 糧を得るために働くという側面のほかに, 生活設計な ど様々な側面をもっている。このため農村女性のキャ リアに関する問題は, 広義の概念を用いて考察するこ とが妥当と思われる.

農村女性について広義のキャリア概念を当てはめる と, キャリア形成之は, 職業経験と人生経験の積み重 ねにより主体を形成していくことを意味する。また， 職業経験と人生経験の積み重ねによって得た経験が将 来への展望とつながる.

安達 ${ }^{1)}$ は, キャリア形成の構成要素として自己概 念と職業観の重要性を述べている. 本稿では, 安達が 示したキャリア形成の構成要素である自己概念と職業 観を用いて農村女性のキャリア形成について考察する.
キャリアを構成するこれらの要素は, 農村生活を通し て外部から得られる情報により変化させられるであろ う。また，キャリア形成についてシャイン2）は，生 涯発達の見地加, 人生において人は常に成長の可能 性があることを示唆した。 また, 生涯発達理論におい て, チクセントミハイはフロー体験という概念を用い て，個人は自己をより複雑なむのにすることで自己を 変形させ, 成長させていく特徵を持っていると述べた $\left(\right.$ 堀 $\left.^{3)}\right)$. このフローを構成する要素は挑戦之能力であ り, これらの要素が低次のレベルから高次のレベルヘ と進んでいく過程において，これらの構成要素が互い に作用しあうことにより人間は発達することを指摘し ている.

鶴見4) は内発的発展論において, 村や地域組織の 内発的発展にはその地に住む定住者間の相互作用と, 定住者と外部からの情報の刺激, 即ち漂泊者との相互 作用が発展を生むとして, 相互作用の重要性について 述べている，個人のキャリア形成には情報の刺激が重 要な役割を示すと思われる.

以下では, 安達が示した概念のほかに情報の重要性 に着目してキャリア形成について考察する，外部情報 から刺激を受けることにより自己概念と職業観が変化 するととあに，両者あ変化すると考えられ相互作用を あたらすと考えられる．農家女性の自己概念之職業観 が情報によ゙のように変化しキャリア形成されていった かを以下で検証する.

\section{3.キャリア形成の構成要素について}

農村女性のキャリア形成の構成要素を図 1 に示した. 構成要素には自己概念と職業観をおき, 外部からの情 報によって自己概念と職業観が相互作用することを提 示した。キャリアを構成する要素の一つである自己概 念は意識と能力と技能が含まれる，主体者自身が意思 決定したことを行動に移す場合, 主体者の意識でその 行動が始まる.つまり, やる気が無ければ行動に移ら ないということである. また, 主体者が事態の変化を 感じとることができる意識も存在する．能力は個人の なかに内在するものであり, 生まれつき備わっている 


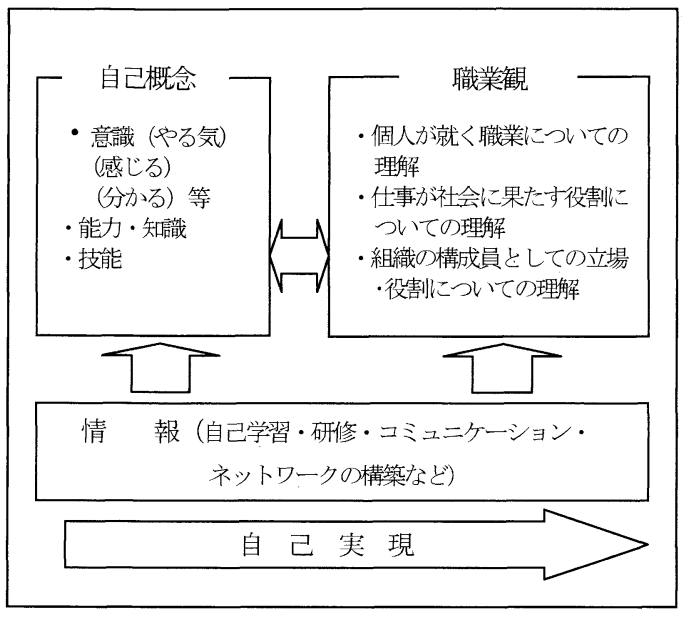

図 1 農村女性のキャリア形成構成要素

あのと後天的なものがある. 後天的な能力は本人の毎 日の積み重文努力によって得られる。仕事を遂行し ていくための大方の能力はこの後天的なあのであり, 自分の努力と経験の積み重ねで培っていくあのである. この能力には, 問題解決力, 創造的思考力, 人間関係 形成力がある ${ }^{5)}$. 次に, 職業の遂行や, 人生を経験し ていくためには様々な知識と技能が要求される，農業 においては経営能力むさることながら, 農業生産に関 する技能を高めることが重要である．この技能をより 高めることよって職業意識にあ変化が現れる。

職業観は, 職業に関する意識を意味し, 個人が就く 職業に関する理解，仕事が社会に果たす役割について の理解, また, 組織や家族経営の構成員としての立場・ 役割についての理解を指している．仕事をしようとす る個人が意識を変化させ，つぎの欲求へと成長してい くためには就く職業に関する理解, 即ち職業観が醸成 されなければならない，かつての農協や現在の JA 組 織, 市町村などの行政組織, また農業改良普及センター では, 農業者に対して研修会などを実施し, 意識改革 への働きかけを行ってきた。 また, 行政や地域で行わ れてきた研修会や, 農村で展開されてきた生活改善運 動が農村女性の意識改革を促し, 職業観への働きかけ を行ってきたといえる．農村女性の職業に関する認識 の度合いによって意識が自己概念にも作用する。また その逆に自己概念の変化が職業観へ作用することも当 然考えられる。このように，キャリアを構成する要素 が相互作用によりダイナミックに変化する可能性があ ることを示唆している，以下では，これに情報という 外部刺激を分析枠組みに加え, 農村女性のキャリア形
成について具体的事例を取り上げ考察する.

\section{4. 事例報告}

以上で提示した農家女性のキャリア形成の分析枠組 みを用いて, 以下では 3 事例についてキャリア形成の 過程を検証する. また, キャリア形成の構成要素が外 部からの情報によってどのように変化していったのか を, 彼女たちの職業経歴や人生経験から検証する.

聞き取り調查によって得られた情報をもとにしてキャ リア形成の過程を図示すると図 2, 表 1 は Iさん, 図

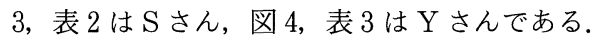

図の横軸はキャリア形成の発達段階を示しており, 就農前期, 学習期, 成長期, 充実期, 自己実現期とし て区分した。学習期は, 新規就農後, 農業の知識や技 能を習得しながら主として補助労働に従事する時期で ある. 成長期は農業への関わり方が前期より次第に充 実し, 役割分担がかなり明確になる時期である. 充実 期は農業生産意欲, 知識, 技能などが更に高くなると 同時に, 農業の果たす役割を深く認識し, 社会的役割 を担いながら主体的に仕事に従事する時期である．自 己実現期は, 就農年限が経過するとともに経験を蓄積 し，キャリア形成が実感できる時期である，そして, 後継者への道筋を開き, 次世代の農業者を育成しなが ら社会貢献をする時期である.

縦軸はキャリアを構成する自己概念之職業観の高ま りの程度を表している. キャリア形成の発達段階を 7 つの要素のマトリックスで形成した. インタビューか ら得た言葉からの情報に基づいて, 筆者らが判断しセ ルに項目を入れ変化と蓄積を表した.

以下では，Iさんの事例について具体的に見ていく ことにする. Iさんは篠山市在住, 64 歳, 就農歷 40 年, 主要な農産物は水稲, 野菜, 英である. 農協に勤 務後，I 氏との結婚を機に就農した．就農前期の個人 意識○1は農協勤務時代で, 農業そのものが好きであっ たことを表している. 成長期, 充実期, 自己実現期の ○は，その意識が時期を経ると共に次第に高くなって いることを表している. 農業の繁栄の必要性を感じて いるのは農協勤務時からである，農業に関して特に影 響を受けた人はお姑さんである，㧍姑さんの仕事を真 似ながら OJTで自分の技能と知識を習得していった 点に特徵がある. 技能はお姑さんのするのを見て同じ ようにする，という○5の表現で示す.また, 表 2 に おいて意識の学習期に $\bigcirc$ で表し, それは表の下部に 表記しているインタビューで得た言葉で判断すること ができる，農業委員や兵庫県女性農漁業士会会長を勤 
めるなどの社会貢献を積んでいることは, 表 2 の区分 である充実期の能力の○11で実証できる. 就農後は, 成長期の社会役割意識の○7 で示すように, 近所の奥 さんたちとネットワークを立ち上げることで表してい る. 良い生産品を作りたい一心から地域ネットワーク 「あゆみ会」の人達と䙵生産の勉強会を開くなど, 技 能と知識の向上に努めたのは知識, 技能 $\bigcirc 8$ で表して いる. 地域社会を巻き込んでの活動展開をするのは社 会役割意識の○13 の言葉の中で地域の人との交流に よって元気をあらうという言葉で証明できる。県女性 農漁業士会会長を次期会長に譲ったのは, 多くの女性 に役職を経験してもらい, 農家の女性が視野を広く持っ て活躍することを期待している，という自己実現期の 意識 $\bigcirc 15$ の言葉で実証できる.

図 2 は, Iさんのキャリア形成過程を表にしたがっ て図示したあのである. 表 1 のルに○を付けたのは 意識の変化とキャリアの蓄積があったと筆者らが判断 した．これを根拠にその蓄積や得た情報の程度を線で 示した。個人意識が, 就職当初は農業が好きという程 度であった，学習期でも同じ農業が好き，であるが， この中身は前のセル段階より高次になっており，(0で 示した.これは, 更に高次へと意識が変化しているこ とを表している. 成長期と充実期の○の数は同じであ る. しかし, 程度が高次に変化している. そのことは, $\bigcirc 12$ の言葉や○11 の女性農業委員を経験しているこ とから判断できる.

図 3, 表 2 , 図 4, 表 3 の見方は Iさんの説明之同

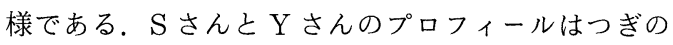
とおりである。

$\mathrm{S}$ さんは, 龍野市在住, 41 歳, 就農歴 11 年, 主と して花苗生産を行っている. 就農前は造園会社に勤務 していた，阪神淡路大震災を機にご主人とともに新規 就農し, 都会から龍野市へ引っ越した。就農当初は言 葉や文化の違いにカルチャーショックを受けたが，そ こからから立ち直って自分の果たす役割を自ら見出し てきた点に特徵がある. 立ち直るきっかけはご主人が 購入してくれたパソコンから情報を得るうちに, 自分 にも出来る仕事があることに気づいたということであ る.

Yさんは, 神戸市北区在住, 54 歳, 就農歴 29 年, 酪農業である。航空会社勤務の経験がある、Yさん はサラリーマン家庭に育ち, 結婚による新規就農であ る. 自然環境を保全しながら, 桃源郷を目指して楽し い毎日を送ることが夢である. 都市住民との交流をと おして事業を発展させている. 大きな影響を受けたの

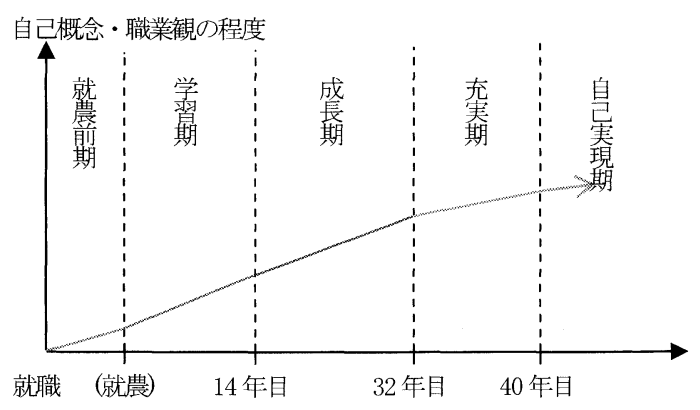

図 2 はさんのキャリア形成過程

表 1 |さんのキャリア形成過程

\begin{tabular}{|c|c|c|c|c|c|c|}
\hline \multicolumn{2}{|r|}{ Iさん } & $\begin{array}{l}\text { 就農 } \\
\text { 前期 }\end{array}$ & 学習期 & 成長期 & 充実期 & $\begin{array}{l}\text { 自己 } \\
\text { 実現期 }\end{array}$ \\
\hline \multirow{4}{*}{$\begin{array}{l}\text { 息 } \\
\text { 概 } \\
\text { 惫 }\end{array}$} & 意識 & & $\bigcirc 4$ & $\bigcirc 6$ & $\bigcirc 10$ & $\bigcirc 15$ \\
\hline & 能力 & & & $\bigcirc 7$ & $\bigcirc 11$ & $\bigcirc 16$ \\
\hline & 知識 & & & $\bigcirc 8$ & $\bigcirc 12$ & \\
\hline & 技能 & & $\bigcirc 5$ & $\bigcirc 8$ & $\bigcirc 12$ & \\
\hline \multirow{3}{*}{ 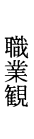 } & 個人意識 & $\bigcirc 1$ & $\bigcirc 1$ & (C) & (C) & (C) \\
\hline & 社会役割意識 & $\bigcirc 2$ & & $\bigcirc 7$ & $\bigcirc 13$ & \\
\hline & $\begin{array}{l}\text { 組織構成員意 } \\
\text { 識 }\end{array}$ & $\bigcirc 3$ & & $\bigcirc 9$ & $\bigcirc 14$ & (a) \\
\hline
\end{tabular}

注：枠内の○はその期に意識があると判断した。は前枠よりさらにグ レードアップしていると判断した. 枠内の 1 から 16 はインタビュー による言葉.

1 農業が好き

2 農業の繁栄に必要性を感じている

3 農協の職員として働く

4 お姑さんがいい物をつくるので, 私むまねをしようと思った

5 お姑さんのするのを見て同じようにやった

6 地域は女の人が元気じゃないと栄えんから

7 近所の家を回って奥さんたちに話をして「あゆみ会」をつくった

8 いい苜をつくるために講習会をして, 勉強した

9 外に会合にでかけるときは, 技姑さんが「おくれんように, はよう いきなさいよ」と言ってくれた, 主人が出ていちゃおいかん,って 言ったことがない

10 女性会の人たちに声をかけて研修会をした

11 女性農業委員

12 普及員さんや農協のひとにいろいろ聞いた

13 いろんな地域の女のひとと交流できて, 何か元気をあらう

14 外に出るからといって, 家の仕事はちゃんとして出ますよ

15 会長を次の人に譲ったから, いろんな人に経験してもらった方が权

16 役は無いけど, あゆみ会の人たちとイベントなどでがんばる

は夫であるが，情報を持ってくるお客さんからも影響 を受けている．司令塔である夫が出す指令を実現する ために研究を重斌, 試行錯誤しながら成果を出してき た点に特徴がある.

\section{5. 考察}

農家女性の 3 事例の考察から, 以下の 4 点が結果と して明らかになった. (1)外部からの情報を入手, 理解, 実行に移すという経緯を踏むことによって意識に変化 がみられた。 Yさんの事例では, 生産品を購入した 


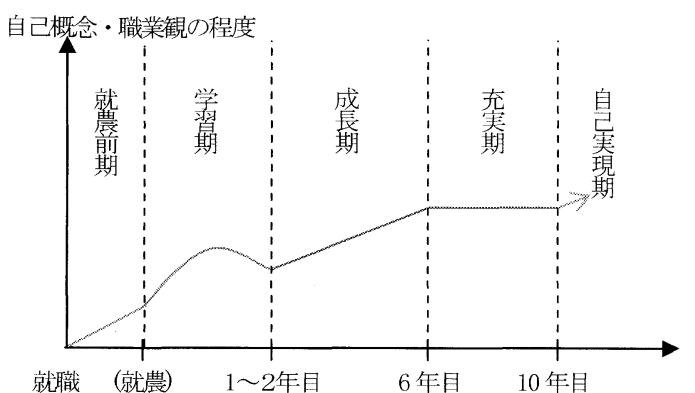

図 3 Sさんのキャリア形成過程

表 2 Sさんのキャリア形成過程

\begin{tabular}{|l|l|c|c|c|c|c|}
\hline \multicolumn{2}{|c|}{$S$ Sさん } & $\begin{array}{c}\text { 就農 } \\
\text { 前期 }\end{array}$ & 学習期 & 成長期 & 充実期 & $\begin{array}{c}\text { 自己 } \\
\text { 実現期 }\end{array}$ \\
\hline \multirow{2}{*}{$\begin{array}{c}\text { 息 } \\
\text { 概 }\end{array}$} & $\bigcirc 1$ & $\bigcirc 3$ & $\bigcirc 7$ & $\bigcirc$ & \\
\cline { 2 - 7 } \\
\cline { 2 - 7 }
\end{tabular}

注：枠内の○はその期に意識があると判断した。は前枠よりさらにグ レードアップしていると判断した，枠内の 1 から 14 はインタビュー による言葉。

1 造園会社で㗢いていた

2 造園の設計をしていたから

3 主人がいきいきと楽しそうに働いているので, よかったなす

4 村や言葉に馴染めず, つらい毎日だった

5 夫がパソコンを買ってくれて，いろいろしてるうちに，じぶんにす できる役割がある，って感じた

6 主人がいきいきと楽しそうに㗢いているので，上かったなお

7 パソコンで出来る仕事を見つけた，花をしている農家さんの奥さん たちとの交流が仕事の意欲につながった

8 自分の役割がはっきりしたら楽しくなったし，だんだん地域の人た ちのことば屯分かるようになった

9 環境のことも考えてしなけ狄ばと

10 新しいことを習いながらやってみる，近所の人はそんなの・・って 言うけど

11 仕事が楽しくなった

12 市の農業大学で寄せ植えの講師の依頼をうけた

13 仕事が楽しくなった

14 兵庫県女性農業士としての働きって地域の人たちに上の情報を流す 役割をもっていると思う

消費者が，その生産品について新たな使い方であると か，食べ方という情報を提供してくれる，その情報を あとに新しい商品開発に取り組み，新製品として生ま れ変わって消費者へ届ける，ということがある。(2)農 業生産のための技術の習得方法, 技術と能力の蓄積方 法を研究しながら生産活動に励むことによって技術や 知識が变化していった．Iさんはよりよい苜の生産に 意欲を持ち, 講習会を開催し生産のための研究を重㸚 る，㧍姑さんのやり方を見て学び，試してみるなどで

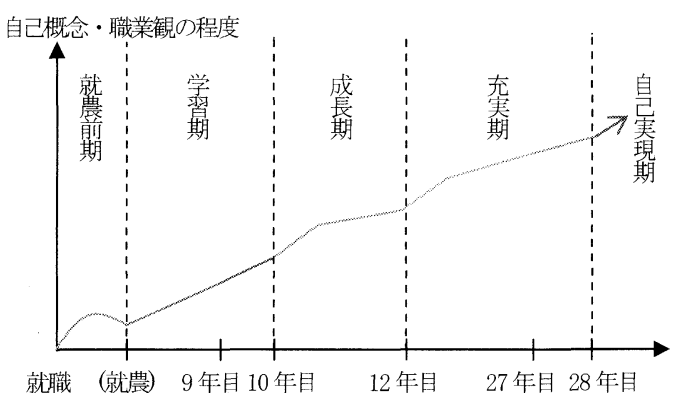

図 4 Yさんのキャリア形成過程

表 3 Yさんのキャリア形成過程

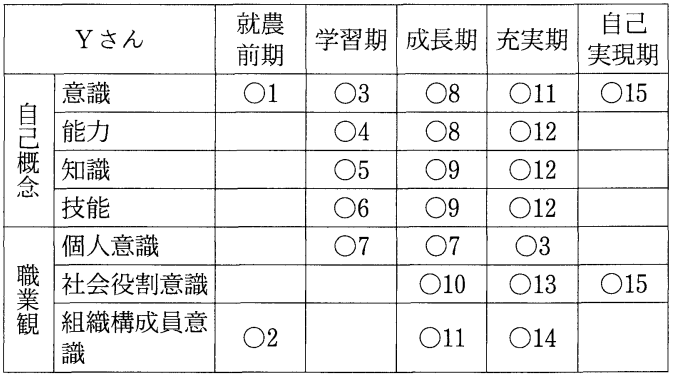

注：枠内の○はその期に意識があると判断した。(○)前枠よりさらにグ レードアップしていると判断した. 枠内の 1 から 15 はインタビュー による言葉.

1 仕事が自分に向いてないと思って, 辞めた

2 会社員として働いていた

3 仕事をまったく知らないので負い目があったから，必死だった

4 夫が司令塔だから

5 カマンベールチーズを作るために，家族でノウハウと菌を持ってい る，ある農場へ行った

6 子供がトイレに入って，鍵をかけてしまって出られなくなった．農 場の人がいろいろしてくれたことがきっかけで菌を分けてあらった． 7 仕事をまったく知らないので負い目があったから, 必死だった 8 カマンベールチーズが失敗ばかりで，あったいないので何とかした

9 いろんな人から聞いて研究した

10 いいものが出来たら，外から情報が来る

11 司令塔の実現を必死でする，打金の工面とか子

12 イベントや料理方法のヒントを下さる方があるの

13 山や自然を守らなくてはね

14 有限会社の取締役です

15 桃源郷を目指しているの

より高い知識や技術を習得するに至った.このような 事例で実証できる。(3)農家女性の農業観は, 経験を蓄 積することによって, 個人的な農業理解程度から次第 に地域へ，さらに広く社会へと広がりをみせていった。 就農当初は自分の農業経営に集中していたが，地域の 女性とネットワークを組んで情報を共有する，という 程度がより高次へと意識が変化し，地域発展に貢献す るという意識に変わっていった。これは，Iさんのあ ゆみ会の結成や， $\mathrm{S}$ さんが同業者の奥さん達の寄り合 
いから得られる情報であり, $\mathrm{S}$ さんの○7 の言葉で現 されている，また，(4)情報は，情報の受け手側の意識, 能力, 環境, 即ち経営面と生活面の状況などによって, 情報の受け取り方や方法, 理解の度合いなど一様でな いことも分かった． Sさんはパソコンから情報を得る ことで，自分にもできる役割があると気づいた，学習 期の○5で現している.これらは, 先述のフロー体験 の構成要素である挑戦と能力の相互作用によって, 自 己をより複雑なものにして自己を変形させていくとい う概念と共通しているといえよう。

\section{6. まとめ}

農村女性のキャリア形成の構成要素の分析枠組みを 構築し, 情報によって自己概念と職業観に変化が生ま れるという理論を構築した。

本稿で取り上げた農家女性の三つの事例とあ, 職業 観が高まるに伴い技能や知識もより高次へと変化をみ せていることが分かった。 また，これらの事例から， 仕事の積み重ねによって得た経験が次の新たな職業経 歴を導き出し，新たな経験を積み重ねることにより農 業者の主体が形成されてきた，ということが分かった。 このように，3人の女性農業者のキャリア形成に関す る検証から, 本稿で仮定したキャリア形成の構成要素 は理論的仮説を支持するあのであったと結論づけるこ とができる。

外部からの刺激を情報という一つの枠に入れたが, 情報という言葉が適切であるか検討する必要がある. 今後はこの情報について，作用の仕方や情報の項目に ついて更に検討したいと考えている，また，より多く の農業者へのインタビューを行い, 事例を蓄積し, キャ リア形成の構成要素の作用について検証することによっ て，農家女性への支援策が一般化できる否かを検討し たい.

注 1) 引用文献 [1] より

2）引用文献 [2] より
3）引用文献 [3] より

4）引用文献 [4] より

5）引用文献 [5] より

森脇は秘書の業務を遂行する能力として秘書業務管理 能力, コミュニケーション能力, 創造的組織活動・協 働活動の推進力の三点を挙げている.これを参考に仕 事をするうえでの能力を導出した。

\section{引用・参考文献}

[1] 安達智子『大学生の職業意識の発達』, 学文社, 2003 年, $\mathrm{p} 43$

[2]エドガーH．シャイン（二村敏子訳）『キャリ アダイナミクス』, 白桃書院, 2002 年, $\mathrm{p} 48$ 〜 49

[3]堀薰夫「生涯学習と自己実現」, 麻生誠 堀薰 共著『放送大学教材 '02』, 放送大学教育振興 会, 2002 年, $p 96 \sim 97$

[4]鶴見和子『内発的発展の展開』, 筑摩書房, 2003 年, p25

[5]森脇道子「大学改革之秘書教育」『秘書学論集』, No. 10,1992 年, $\mathrm{p} 10$

[6]濱口恵子「内発的発展論研究における内発性の 再検討」『農林業問題研究』, 第 154 号 第 40 巻 第 1 号, 2004 年

［7］田代洋一『日本農村社会の主体形成』筑波書房, 2004 年

［8］霍 理恵子「農家女性のエンパワーメント促進 する背景とその要因」『村落社会研究』, 第 9 巻 第 2 号, 2003 年

[9]金井壽宏『働くひとのためのキャリアデザイン』, PHP 研究所, 2004 年

<付記 >

本研究は平成 $16 \cdot 17$ 年度科学研究費 (基盤研究 (C) 研究 課題「農村女性のキャリア形成に関する研究」）の補助を得 ている. 